\title{
REMEMBRANCE OF THE BORKI TRAIN DISASTER IN THE EPARCHIAL PART OF "FAITH AND REASON"
}

\begin{abstract}
In the Russian empire of the 19th century, every important event in the life of the ruling dynasty became newsbreak for various periodicals. On October 17, 1888, all the carriages of the imperial train were wrecked at Borki (Kharkiv province and eparchy). There were 23 victims and 35 badly wounded in the disaster, but the emperor Alexander III, his wife and children escaped without serious injury. In the view of the state religion, this miraculous salvation was considered to be a divine blessing and was consequently immortalized in an hermitage near Borki, by charitable institutions, etc. The study of these practices can help amplify the lore about the politics of remembering and representations of memory about the sovereign. The case of the Kharkiv region, where the crash took place is scantily investigated. This work deals with the materials about the Romanovs' survival, published in both official and unofficial parts of the main Orthodox magazine of the Kharkiv eparchy during 1889-1915. The author studies the contexts of all mentionings about the disaster and concludes that these publications were connected mainly with annual commemorative events near Borki, but they were not the essential part of each October issue.
\end{abstract}

Keywords: Kharkiv eparchy in 1889-1915; commemoration; Russian empire; Romanov family; Saviour's skete.

In the Russian empire of the $19^{\text {th }}$ century, every important event in the life of the ruling dynasty became newsbreak for various periodicals.

On October 17, 1888, all the carriages of the imperial train were wrecked at Borki (Kharkiv province and eparchy). There were 21 victims and 35 badly

* “Igor Sikorsky Kyiv Polytechnic Institute”, Kyiv; Ukraine. 
wounded (two of them died later) in the disaster, but the emperor Alexander the $3^{\text {rd }}$, his wife and children escaped without serious injury (Wortman 311).

In the view of the state religion, this miraculous salvation was considered to be a divine blessing and was consequently immortalized by various commemorative practices: the arrangement of a hermitage near Borki, charitable institutions, etc. The imperial manifesto of October 23, 1888 stated that the miracle was not only the result of divine intervention: it was God's response to the prayers and holiness of the Russian people. According to R. S. Wortman, the invocation of this miracle also fundamentally changed the tsar's scenario and brought it closer to the veneration of the increasingly popular miraculous icons (Wortman 310-1).

The study of commemorative practices related to the Borki train disaster can help amplify the lore about the politics of remembering and representations of memory about the sovereign. The case of the Kharkiv region, where the crash took place is scantily investigated. Kolovrat-Butenko reached the conclusion that the perception of the emperor's survival as a miracle played a decisive role in the fate of all microregions around the Borki station ${ }^{23}$, but focused mainly on the history of the Saviour's skete at the site of disaster.

This work deals with the materials about the Romanovs' survival, published in both official and unofficial parts of the main Orthodox magazine of Kharkiv eparchy during 1889-1915.

Since 1884, this journal was entitled "Faith and Reason" ("Вера и разум") instead of "Kharkov Eparchial Herald" ("Харьковские епархиальные ведомости"). In October 1915, its eparchial part was transformed into the separate journal "Shepherd and Flock" ("Пастырь и паства"). Each parish was required to subscribe to this journal ${ }^{24}$.

During this period, several chief editors changed (Table 1).

Table $1^{25}$.

\begin{tabular}{|l|l|}
\hline $1884-1893$ & archpriest I. Kratirov \\
\hline $1893-1894$ & archpriest A. Martynov \\
\hline $1894-1899$ & I. Znamenskiy \\
\hline $1899-1906$ & archpriest I. Znamenskiy \& K. Istomin \\
\hline
\end{tabular}

${ }^{23}$ Коловрат-Бутенко 15.

24 Бабанина; Троицкий.

${ }^{25}$ Вера и разум. 
University of Bucharest Review $\approx$ Vol.X/2020, no. 2 (new series)

\begin{tabular}{|l|r|}
\hline \multicolumn{2}{|c|}{ Re-writing, Re-imagining the Past (II) } \\
\hline $1906-1916$ & archpriest A. Yushkov \& K. Istomin \\
\hline
\end{tabular}

It was taken into account the fact that the magazine was censored, and the editorial board had to adapt to this, especially in publications that mentioned persons from the imperial dynasty.

This study has the following main objectives: first of all, it is important to detect the links between the dates of the disaster itself and the publications about it. The next questions are related to the authorship, content and style of the materials. The study is based on the principles of historicism and objectivity.

The methods of source heuristics and critique, comparative history and generalizing are used to outline the historical context.

The magazine was biweekly and materials about the Borki disaster were annually published in the issues 20 (October 31) ${ }^{26}, 21$ (November 15) ${ }^{27}$, and $22^{28}$.

In 1894, the emperor Alexander the 3 died on October 20 after a long illness (Wortman 313). That is why the editors of "Faith and Reason" did not highlight his miraculous survival in 1888 that year. There were also no mentionings about the disaster in 1897, 1900, 1902, 1911. The reasons for these gaps need separate research.

The official part of the magazine contains only two materials related to the research theme.

In the \# 20 (1895), the "highest gratitude" was expressed to the parishioners of the Nativity of the Theotokos Church from Mykolaivka village in Kharkiv eparchy, exclusively peasant owners, for covering the icon of the Saints celebrated by the Church on October 17 with a silver icing frame. This action was considered to be a manifestation of loyal and religious-patriotic feelings ${ }^{29}$.

\footnotetext{
2616 октября, в понедельник 1030-1031; 17 октября... 273; 17 октября, в 13-ю 503; 17 октября в г. Харькове и в Спасовом скиту 488-489; 17 октября, в годовщину крушения 327; 17 октября, в день 16-й 1013; 17 октября в Спасовом скиту 272-275; Высочайшая благодарность 503; Закладка часовни 545-547; Отчет о 964; С чувством 510-511; Торжества 524-526; Торжественное богослужение 601.

2717 октября, в годовщину 400; 17-го октября, в день годовщины 411; Высочайшая отметка 567; Октябрь. 17-го 407-408; Отчет епархиального 571) or both 20 and 21 (17 октября, в день второй годовщины 570-571; 2 ноября 556; 29 октября после литургии 556-557; Берлинская русская православная община 558; В среду 17 октября607-608; О чудотворном образе Спаса 559-560; Празднование 17-го октября 543-550; Убитые при катастрофе поезда 560.

${ }^{28}$ Нам сообщают из Ново-Екатеринослава 588-9.

${ }^{29}$ Высочайшая благодарность 503.
} 
In the \#21 (1898), the "highest gratitude" was expressed to the cabmen from Kharkiv for the icon of the Saints celebrated by the Church on October 17 and the Saint Patrons of the Emperor's family, in silver gilded frame, donated to the Kharkiv Annunciation Church. The intention of the donors to give annual thanksgiving prayers in honour of the salvation of the emperor and his family in front of this icon was especially emphasized ${ }^{30}$.

Two of them (1889 and 1892) refer respectively to the magazine "Kharkiv Provincial Herald" ("Харьковские губернские ведомости") ${ }^{31}$ and newspaper "Kharkiv Herald" (“Харьковские ведомости") 32, and two of them (1891 \& 1896) refer to the daily newspaper "Southern Region" ("Южный край") 33 .

As to the content of the articles from other press organs, the article "Celebration on October 17 at Svyatogorsk Saviour's skete" from \#20 of "Kharkiv Provincial Herald" (1889) contains the detailed history and description of the Saviour's hermitage near the scene of the accident (including the blood-red painted cross and fence on the victim's grave), complete with the description of the celebrations in this sacred place, at the time of the $1^{\text {st }}$ anniversary of the miraculous salvation. Its anonymous author emphasized the special solemnity of all ceremonies in Kharkiv and in the Saviour's skete, as well as the description of all improvements near the places where different cars were located during the disaster, with special emphasis on the increasing roominess of the temporary wooden church. It is also indicated who (peasants from Sokolove village, and the landowner Mernenko) donated the land plots to the skete $^{34}$. The author mentioned that masses of people took regular and additional trains, drove horse carriages or arrived on foot from the surrounding villages to thank God for the manifestation of His unlimited mercy and to get acquainted with the state of the great patriotic work undertaken here to commemorate the miraculous event ${ }^{35}$.

In 1891, the editors of "Faith and Reason" borrowed from "Southern Region" a report on the visit of the emperor's retinue and then of the Romanov imperial family, Danish king and queen, and Welsh princess with her daughter

\footnotetext{
30 Высочайшая отметка 567.

31 Празднование 17-го октября 543-50; С чувством 510-1.

32 Празднование 17-го октября 543-50.

33 Торжества 524-6.

${ }^{34}$ Празднование 17-го октября 543-50.

35 Празднование 17-го октября 546.
} 
to the accident site. The anonymous author described the timetable of all ceremonies, the features of thanksgiving and memorial prayer services with the list of participating hierarchs and other clergy, the conversations about church building in the Saviour's skete ${ }^{36}$.

In 1892, the editors of "Faith and Reason", on the base of "Kharkiv Provincial Herald" published statistics of material manifestations of loyalty to the emperor and his family, related to the event of 1888 (new churches and altars, chapels, icon screens, bells, charity institutions etc.) ${ }^{37}$.

The article of 1896 with reference to «Southern Region» is a literal exposition of the report from the celebrations in Borki, with a list of participants to the liturgy, the thanksgiving prayer service, and the religious procession with the icon of Our Lady of Ozeriany in Borki. This list contains the names and titles of the hierarchs, other clergy as well as of the high-ranking lay officials (both civil and military). The second borrowed part of this report deals with a thanksgiving prayer service in Kharkiv Dormition cathedral. The third part of the report in "Southern Region" ("Church Military Display") was not included in the magazine ${ }^{38}$.

It is significant that a commentary on the role of the icon of Our Lady of Ozeriany as a powerful means of attracting worshipers to Borki was not removed when the material was reprinted from "Southern Region" 39 . This comment also appeared in the travelogue by a certain Putnik (1896) ${ }^{40}$ and in the announcement on the celebrations (October 17, 1897), published by the priest of Kharkiv Cathedral ${ }^{41}$.

The Orthodox believers worshipped the Marian icon from Ozeriany as the main sacred object of Kharkiv and the entire Sloboda Ukraine ${ }^{42}$. Perhaps great crowds gathered in Borki primarily to venerate the revered icon once again. For example, one of the articles on the Borki celebrations (1909) contains the information that after the service, the Ozeriany icon remained in the church of

\footnotetext{
${ }^{36}$ В половине десятого часа 407-8.

${ }^{37}$ С чувством 510-511.

38 День 17-го октября 2; Торжества 524-6.

39 Торжества 524.

${ }^{40}$ Путник 2.

${ }^{41}$ Виноградов 1.

42 Об особой любви 156-63.
} 
Borki until the train departed for Kharkiv, and all this time numerous people continuously worshipped it ${ }^{43}$.

The note on the consecration of a church dedicated to The Entry of the Most Holy Theotokos into the Temple in the Saviour's skete near Borki (Ill. 1), published in the \#21 (1889), contains the information about the visit of Mykhail Romanov to this sacred place. There is also a list of hierarchs, other clergy and of high-ranking lay officials. This material announces the placement of the speech by Kharkiv Archbishop Ambrose in this issue ${ }^{44}$. However, there is no speech on its pages. The same situation is reproduced in the \#20 (1903) with the speech by the Bishop Stephen announced in the material "Solemn service and church parade on October 17", on the $15^{\text {th }}$ anniversary of Borki miracle ${ }^{45}$, as well as in the \#20 (1904) with the sermon by the Archbishop Ambrose announced in the material on the Borki miracle, published at the beginning of "this book" 46 . Therefore, some materials probably contain gross undocumented borrowings from the other press organs.

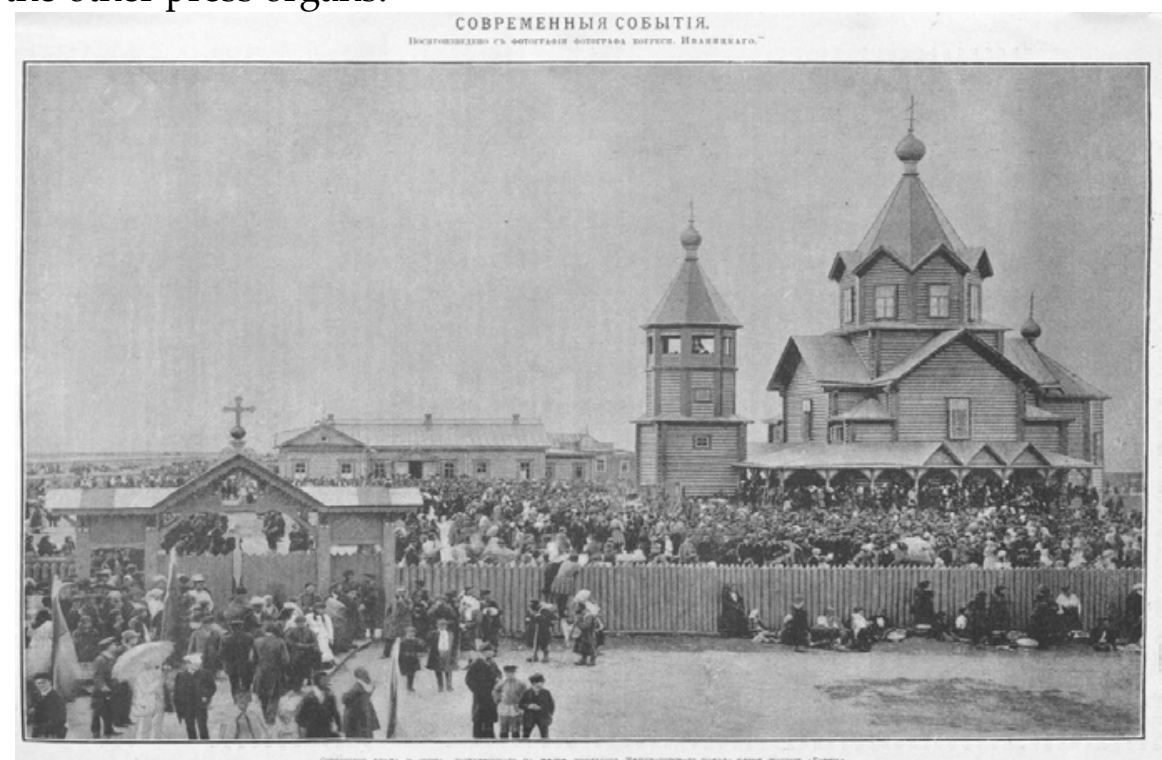

43 17-го октября, в день годовщины 411.

442 ноября 555-6.

45 Торжественное Богослужение 601.

4617 октября, в день 16-й 1013. 
Fig. 1. Consecration of a church dedicated to The Entry of the Most Holy Theotokos into the Temple in the Saviour's skete near Borki. Copy of the photo by correspondent Ivanitski ${ }^{47}$.

Less or more detailed reports from the commemorative celebrations have been published without direct or 'hidden' links to other journals or newspapers in 1890 and 1891 (in Borki) ${ }^{48}, 1893$ (in Borki and Kharkiv) ${ }^{49}, 1901$ and 1906-1908 (in Borki) 50, 1909 (in Borki and Kharkiv) 51, 1910 and 1913 (in Borki) 52, 1914 (in Borki and Kharkiv) ${ }^{53}$.

The death of Alexander the $3^{\text {rd }}$ did not have a significant impact on the style of such publications. Only the mention that the singing of "Polychronion" chanted for him ${ }^{54}$ was replaced by the singing of "Eternal memory" 55 . In 1909, the consecration of the monument to Alexander the $3^{\text {rd }}$ in the Saviour's skete was described in detail (17-го октября, в день годовщины 411). It is also interesting that the memorial service for victims of the disaster is not necessarily mentioned ${ }^{56}$ in the researched articles.

The shortest mention (1914) consists of one sentence:

On October 17, on the anniversary of the crash of the Imperial train near the station Borki, His Eminence Archbishop Anthony celebrated Divine Liturgy with a prayer service in the Saviour's Cathedral at the site of the miraculous salvation of the Emperor and His family during a train crash, and His Grace Bishop Theodore performed Divine Liturgy with a prayer service in Kharkiv Cathedral. ${ }^{57}$

47 Освящение 173.

48 В среду 607-8; Закладка часовни 542-4.

4917 октября в г. Харькове 488-9.

5017 октября, в 13-ю 503; 16 октября 1030-1031; 17 октября... 273; 17 октября в Спасовом скиту 272-5.

51 17-го, в день годовщины... 411.

52 Октябрь. 17-го 407-8; 17 октября, в годовщину 400.

5317 октября, в годовщину крушения 327.

5417 октября, в день второй годовщины 571.

5517 октября, в день 16-й годовщины 1013; 17 октября... 273.

5617 октября... 273; 17 октября, в день 16-й годовщины 1013; 17-го октября, в день годовщины 411; Октябрь. 17-го 408.

57 “17 октября, в годовщину крушения Царского поезда бдиз ст. Борки, Высокопреосвященнейший Архиепископ Антоний совершил Божественную дитургию с 
University of Bucharest Review $\approx$ Vol. X/2020, no. 2 (new series)

Re-writing, Re-imagining the Past (II)

First of all, the authors described the timetable of the ceremonies ${ }^{58}$, the features of thanksgiving or memorial prayer services ${ }^{59}$, and religious procession with the icon of Our Lady of Ozeriany in Borki with the list of the hierarchs, other clergy and of the high-ranking lay officials (both civil and military) ${ }^{60}$.

Since Saviour's skete was under construction, these authors also noticed the progress in its development ${ }^{61}$. The short untitled article (1891) deals with the foundation of memorial chapel at the site of the October 17, 1888 disaster and with the visit of Romanov family to the ceremony ${ }^{62}$.

It was customary to emphasize the large number of pilgrims, sometimes with the mention of their regional and (or) social diversity ${ }^{63}$. Photos of the most significant commemorative events (Fig. 1, Fig. 2) can help imagine what number of pilgrims was considered to be large.

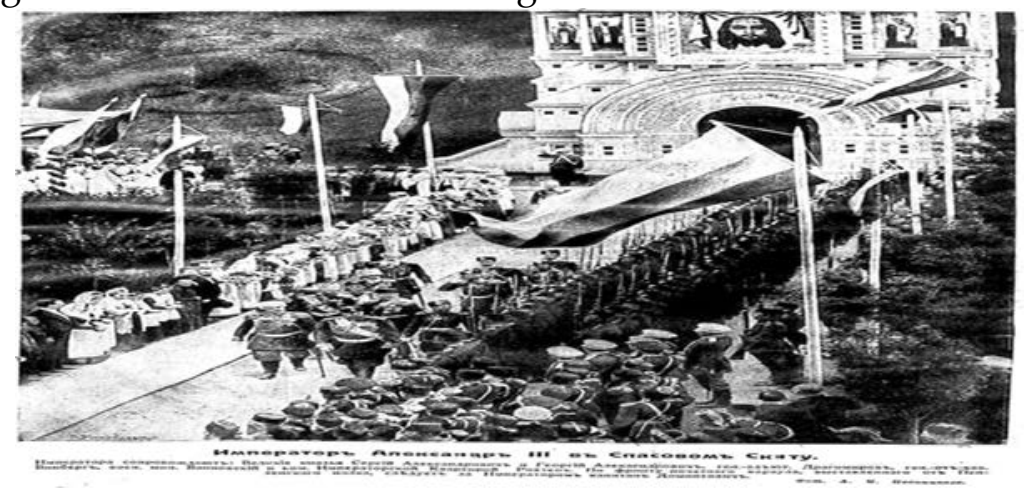

молебствием в храме Христа Спасителя на месте чудесного спасения Царской семьи при крушении поезда, а Преосвященнейший Епископ Феодор Божественную литургию с молебствием совершил в Харьк. Кафедральном соборе" (17 октября, в годовщину крушения 327).

5816 октября, в понедельник 1030; 17 октября... 273; 17 октября, в годовщину 400; 17 октября, в день второй годовщины 570-1; 17-го, в день годовщины; Закладка часовни 545-547; Октябрь. 17-го 407-8.

5916 октября, в понедельник 1030-1031; 17 октября... 273; 17 октября в г. Харькове и в Спасовом скиту 488; 17 октября, в день второй годовщины 570-1; 17-го, в день годовщины; Закладка часовни 545-7; Октябрь. 17-го 407-8.

6016 октября, в понедельник 1031; 17 октября... 273; Октябрь. 17-го 407-8.

6117 октября, в день второй годовщины 571; 17 октября, в 13-ю годовщину 503.

62 Закладка часовни 545-7.

6316 октября, в понедельник 1031; 17 октября, в день второй годовщины 571; 17 октября в г. Харькове и в Спасовом скиту 488; 17 октября, в 13-ю годовщину 503; Закладка часовни 545-7; 17 октября в г. Харькове и в Спасовом скиту 488; Октябрь. 17-го 407. 
University of Bucharest Review $\approx$ Vol. X/2020, no. 2 (new series)

Re-writing, Re-imagining the Past (II)

Fig. 2. The emperor Alexander the $3^{\text {rd }}$ in the Saviour's skete. Photo by Ivanitsky ${ }^{64}$

The more detailed articles contain information about decorating the railway station with flags ${ }^{65}$, illumination ${ }^{66}$, charity or guest dinners for visitors ${ }^{67}$, military church parades ${ }^{68}$, performance of the hymns "How Glorious Is Our Lord in Zion" and "God Save the Tsar!" 69, ordinations to the deacon- or priesthood during celebrations $\mathrm{s}^{70}$, political speeches in support of the emperor ${ }^{71}$.

The articles mostly lacked vivid expressions of the author's emotions. An exception is the report on the $20^{\text {th }}$ anniversary of the events of 1888. In 1908, due to a coincidence, secular administrators were unable to attend. Kharkiv city selfgovernment, for unknown reasons, was absent, except for two or three random members. The anonymous author of the publication stated that despite the absence of embroidered uniforms, the day passed very solemnly. However, his attention was drawn to the poor condition of the Saviour's Cathedral in Borki. The Cathedral looked neglected and untidy despite the large funds allotted from the state budget each year. The author emotionally expressed surprise that be the church was in charge of the same railway department, which had caused the terrible catastrophe ${ }^{72}$. This is the only report that contains certain critical remarks about the celebrations.

In 1889, the magazine received and published message about the celebration of the October 17 in the former state settlement Novo-Katerynoslav.

According to this report, "the significant, sacred day" was celebrated especially solemnly there, because it was also the consecration day of the new house church in the abolished military-settlement house, in memory of the rescue of the emperor and his family from mortal danger ${ }^{73}$.

\footnotetext{
${ }^{64}$ Император.

6517 октября в г. Харькове и в Спасовом скиту 488; Закладка часовни 545.

6617 октября в г. Харькове и в Спасовом скиту 488.

6717 октября, в день второй годовщины 571; Закладка часовни 547.

6817 октября, в день второй годовщины 571; Закладка часовни 545.

69 17-го, в день годовщины 411.

7017 октября, в годовщину 400.

${ }^{71} 17$ октября... 273.

7217 октября в Спасовом скиту 272-3.

${ }^{73}$ Нам сообщают 588-9.
} 
The events are described according to the same scheme as in the reports about the celebrations in Borki and Kharkiv. The role of merchants led by Babin in the founding of the church is additionally emphasized ${ }^{74}$.

In 1890, the editors of "Faith and Reason" published a special correspondence from Akhtyrka on the consecration of a brick memorial chapel devoted to the Borki miracle on the fence of the Dormition church. The note contains a list of clerical participants ${ }^{75}$.

According to the mentioned material, due to the religious procession with the Marian icon from Ozeriany, the event on October 17 acquired "the features of an all-round celebration with the participation of representatives of the city, the command of the local regiment, students and attracted many prayers for the health and well-being of the beloved monarch and his family ${ }^{76}$. The chapel was built thanks to donations from ordinary parishioners and mainly ensign Jacob Stelletsky and peasant Anthony Chikalo. The author stressed that the required 2000 rubles were not easy to collect on time ${ }^{77}$.

The \#21 of 1889 contains four uncharacteristic materials.

The $1^{\text {st }}$ is a paraphrased speech to students, of the trustee of the Kharkiv educational district, Nicholai Vorontsov-Veliaminov about an initiative of their comrades, fulfilled with filial, sincere and loyal feelings, to visit Borki and order a thanksgiving prayer there. Vorontsov-Veliaminov also explained the significance of the imperial gratitude for showing such feelings and urged to stay true to patriotic spirit ${ }^{78}$.

The $2^{\text {nd }}$ is a report on the emperor's recent stay in Berlin. The author mentioned the gifts from the Russian diaspora, on the anniversary of the Borki miracle ${ }^{79}$.

The $3^{\text {rd }}$ is an essay "About the Miraculous Image of the All-Merciful Saviour, Who Was with the Emperor's family on October 17, as It Was Always with Them Before" 80 .

\footnotetext{
${ }^{74}$ Нам сообщают 588-9.

75 Корреспонд[ент] Иистка 607-8.

76 «...имело характер торжества всесословного, с участием представителей города, начальников местного полка, учащих и учащихся, и привлекло великое множество молящихся о здравии и благоденствии нашего возлюбленного Монарха и Его Царской Семьи» (Корреспонд[ент] Аистка 608).

77 Корреспонд[ент] Аистка 607-8.

7829 октября 556-7.

79 Берлинская 558.
} 
The $4^{\text {th }}$ reports in detail that six lower ranks of the railway battalion, killed in the train crash were first buried in the Kharkiv city cemetery, without military honours, but were later moved, by imperial order, to a more prominent place ${ }^{81}$.

In 1892 (\#20), the anonymous author highlighted in detail the opening of a "Society of Adherents of Faith and Mercy" in Saint-Petersburg on October 22. He also emphasized that the society originated from the memory of a miracle near Borki $^{82}$.

Sometimes the mentions about Borki miracle were included into the broader activity reports.

In 1899 (\#21), the eparchial observer, in his report on the state of the parochial schools and schools of literacy in the Kharkiv eparchy for the 1897 academic year noted the stories told to pupils by the catechists on October 17, about the miraculous salvation of the emperor's family in the wreckage of a railway train ${ }^{83}$.

The "Report on the activities of the Kharkiv Diocesan Brotherhood in the Name of the Ozeriany Theotokos" published in 1905 (\#20) contains a mention about the reading of didactic materials related to the Borki miracle by the members of the brotherhood to illiterate believers ${ }^{84}$.

In 1891 (\#20), the magazine published the news about the opening of a fountain dedicated to the events on October 17 by Muslims in Bakhchisaray. The anonymous author explained the choice of this form of commemoration and described the memorial and inscriptions on $\mathrm{it}^{85}$.

The mention that the celebration of the $400^{\text {th }}$ anniversary of Zindjerly madrasah was timed to coincide with this day seems similar to the situation with the delivery of the miraculous icon to Borki during the celebrations ${ }^{86}$.

\section{Conclusion}

It is possible to make a conclusion that the publications related to the Borki train disaster dealt mainly with current annual commemorative events in Borki

\footnotetext{
${ }^{80}$ О чудотворном образе Спаса 559-60.

81 Убитые 560.

8222 октября 512.

83 Отчет епархиального 571.

${ }^{84}$ Отчет о деятельности 964.

85 Памятник фонтан 548.

${ }^{86}$ Памятник фонтан 548.
} 
and Kharkiv, or sometimes in other places.

However, these materials were not the essential part of each October issue. The reprints of texts that had already passed censorship, as parts of other media were preferred on occasion, albeit to the detriment of publication promptness. It was necessary to investigate the conditions on the basis of which materials for "Faith and Reason" were taken from other publications.

The reasons for the lack of information about the celebrations on October 17 in different places of the eparchy (except Novo-Katerynoslav and Akhtyrka) require additional research. An analysis of additional sources can help answer the question whether it was a free choice of the editorial board or it was due to a general lack of celebratory activities.

The reviewed articles were not signed. Most of them could be considered as largely formulaic "editorials". The anonymous authors paid attention to the ceremonial order, rather than to the religious spirit of celebrations.

It is possible to argue that the "Faith and Reason" editorial board (a manifestation of allegiance to the emperor, his family, and state) was forced to select the materials about the Borki disaster with an eye for censorship.

\section{Works Cited}

“2 ноября...". Аисток для Харьковской епархии при богословско-философском журнале "Вера и разум" 21 (Известия и заметки) (1889): 556. Print.

"16 октября, в понедельник". “Вера и разум 20 (Отдел 3: Известия и заметки по Харьковской епархии) (31.10.1906): 1030-1031. Print.

“17 октября...". Вера и разум 20 (Отдел 2: Известия и заметки по Харьковской епархии) (31.10.1907): 273. Print.

“17 октября, в 13-ю годовщину...". Аисток для Харьковской епархии при богословско-философском журнале “Вера и разум» 20 (Известия и заметки) (31.10.1901): 503. Print.

“17 октября в г. Харькове и в Спасовом скиту". Аисток для Харьковской епархии при богословско- Философском журнале “Вера и разум" 20 (Известия и заметки) (31.10.1893): 488-489. Print.

“17 октября, в годовщину...”. Вера и разум 21 (Отдел 2: Известия и заметки по Харьковской епархии) (15.11.1913): 400. Print.

“17 октября, в годовщину крушения...” Вера и разум 20 (Отдел 2: Известия и заметки по Харьковской епархии) (31.10.1914): 327. Print. 
University of Bucharest Review $\approx$ Vol. X/2020, no. 2 (new series)

Re-writing, Re-imagining the Past (II)

“17 октября, в день 16-й годовщины...". Известия по Харьковской епархии при богословско-философском журнале “Вера и разум" 20 (31.10.1904): 1013. Print.

“17 октября, в день второй годовщины”. Аисток для Харьковской епархии при богословско-философском журнале "Вера и разум" 20 (Известия и заметки) (31.10.1890): 570-1. Print.

“17-го октября, в день годовщины чудесного спасения Царской семьи” Вера и разум 21 (Отдел 2: Известия и заметки по Харьковской епархии) (15.11.1909): 411. Print.

“17 октября в Спасовом скиту” Вера и разум 20 (Отдел 2: Известия и заметки по Харьковской епархии) (31.10.1908): 272-5. Print.

“22 октября в зале заседаний”. Аисток для Харьковской епархии при богословско-философском журнале "Вера и разум" 20 (Известия и заметки) (31.10.1892): 512. Print.

“29 октября после литургии”. Аисток для Харьковской епархии при богословско-философском журнале "Вера и разум" 21 (Известия и заметки) (15.11.1889): 556-7. Print.

Wortman, Richard. Scenarios of Power: Myth and Ceremony in Russian Monarchy from Peter the Great to the Abdication of Nicholas II. Columbia: Princeton University Press, 2006. Print.

Амвросий, архиеп. “Об особой любви и усердии народном к чудотворной иконе Божией Матери в нашем крае...". Собрание слов и речей высокопреосвященного Арсения (Брянцева), архиепископа Харьковского и Ахтырского, говоренных в разных местах его служения. Т. 5: 1909-1912 гг. Харьков: Мирный труд, 1912: 156-63.

Бабанина, Т. Л. “Вера и разум”. Православная энциклопедия. Москва, 2004. Т. VII: 700-1. Print.

“Берлинская русская православная община”. Аисток для Харьковской епархии при богословско- философском журнале “Вера и разум" 21 (Известия и заметки) (15.11.1889): 558. Print.

“В половине десятого часа”. Дисток для Харьковской епархии при богословско-философском журнале “Вера и разум" 20 (Известия и заметки) (31.10.1891): 542-4. Print.

“Вера и разум” 16.05.2020. Web. 01 Sep. 2021 <https://cutt.ly/sEaQGFA>.

Виноградов, Григорий. “Объявление”. Южнъй край 5420 (16.10.1896): 1. 
University of Bucharest Review $\approx$ Vol. X/2020, no. 2 (new series)

Re-writing, Re-imagining the Past (II)

“Высочайшая благодарность". Аисток для Харьковской епархии при богословско-философском журнале “Вера и разум" 20. (31.10.1895): 503. Print.

“Высочайшая отметка". Аисток для Харьковской епархии при богословскофилософском журнале "Вера и разум" 21 (15.11.1898): 567. Print.

“День 17-го октября в Спасовом скиту”. Южный Край 5422. (18.10.1896): 2. Print.

“Закладка часовни на месте события 17 октября 1888 г...”. Аисток для Харьковской епархии при богословско-философском журнале “Вера и разум" 20 (Известия и заметки) (31.10.1891): 545-7. Print.

“Император Александр III в Спасовом Скиту”. Web. 01 Sep. 2021 < https://cutt.ly/WEbVQyd>.

Коловрат-Бутенко, Юрий. Спасов Скит. Крушение цุарского поезда и история храла Христа Спасителя. Саарбрюккен: LAP, 2016. Print.

Корреспонд[ент] Аистка. “В среду 17 октября". Аисток для Харьковской епархии при богословско-философском журнале “Вера и разум" 21 (Известия и заметки) (15.11.1890): 607-8. Print.

“Нам сообщают из Ново-Екатеринослава”. Аисток для Харьковской епархии при богословско-философском журнале "Вера и разум" 22 (Известия и заметки) (30.11.1889): 588-9. Print.

“О чудотворном образе Спаса Всемилостивого, который был с семейством государя 17 октября, как неотлучно бывал он при них и прежде". Аисток для Харьковской епархии при богословско-философском журнале “Вера и разум" 21 (Известия и заметки) (15.11.1889): 559-60. Print.

“Октябрь. 17-го, в воскресенье”. Вера и разум 21 (Отдел 2: Известия и заметки по Харьковской епархии) (15.11.1910): 407-8. Print.

“Освящение храма и скита, сооружённого на месте крушения Императорского поезда близ станции Борки. 20 августа 1889 года". Живописное обозрение 37. 1889 (10.09.1889): 173. Print.

“Отчет епархиального наблюдателя о состоянии церковно-приходских школ и школ грамоты Харьковской епархии по учебновоспитательной части за 1897 учебный год". Аисток для Харьковской епархии при богословско-философском журнале "Вера и разум"21 (15.11.1899): 571. Print.

“Отчет о деятельности Харьковского Епархиального Братства во имя Озерянской Божией Матери со времени его открытия 25 января 1904 
University of Bucharest Review $\approx$ Vol. X/2020, no. 2 (new series)

Re-writing, Re-imagining the Past (II)

года по 1 октября 1905 года". Вера и разум 20 (Отдел 3: Известия по Харьковской епархии) (31.10.1905): 964. Print.

"Памятник фонтан". Аисток для Харьковской епархии при богословскофилософском журнале “Вера и разум" 20 (Известия и заметки) (31.10.1891): 547-8. Print.

Путник. “В Спасов скит (путевые заметки).” Южный Край 5423. (19.10.1896): 2. Print.

“Празднование 17-го октября в Святогорском Спасовом ските”. Аисток для Харьковской епархии при богословско20 (Известия и заметки) (31.10.1889): 543-50. Print.

“С чувством трепетного и неописуемого удивления...". Аисток для Харьковской епархии при богословско- философском журнале "Вера и разум" 20 (Известия и заметки) (31.10.1892): 510-1. Print.

“Торжества в день 17 октября в Спасовом скиту и в г. Харькове”. Аисток для Харьковской епархии при богословско-философском журнале "Вера и разум" 20 (Известия и заметки) (31.10.1896): 524-6. Print.

“Торжественное богослужение и церковный парад 17-го октября". Аисток для Харьковской епархии при богословско-философском журнале "Вера и разум" 20 (Известия и заметки) (31.10.1903): 601. Print.

Троицкий, Александр. "Епархиальные ведомости." Православная энциклопедия. 2014. Web. 01 Sep. $2021<$ https://cutt.ly/dEaQLCe>.

“Убитые при катастрофе поезда...". Аисток для Харьковской епархии при богословско-философском журнале “Вера и разум" 21 (Известия и заметки) (15.11.1889): 560. Print. 